\title{
Meanings of Old Age to the Elderly in Pondok Living Arrangement in Malaysia
}

\author{
Nor Aisah Areff' 1 \\ Novel Lyndon² \\ ${ }^{1}$ Lecturer, Department of Sociology and Anthropology, Kulliyyah of Islamic Revealed Knowledge and Human Sciences, \\ International Islamic University Malaysia; norareff@yahoo.com \\ ${ }^{2}$ Associate Professor, School of Social, Development and Environmental Studies, Faculty of Social Sciences and Humanities, \\ Universiti Kebangsaan Malaysia; novel@ukm.edu.my
}

\section{Doi:10.5901/mjss.2015.v6n4s3p32}

\begin{abstract}
Previous studies have focussed on the meaning of old age as conducted from the quantitative approach. Thus the primary emphasis of this article is the perception of elderly individuals who resided in Pondok Jeram, an alternative congregated living arrangement which was established for the propagation of Islamic teaching and learning on old age. The employment of abductive research strategy based on idealist ontology and social constructionist epistemology gave the perennial importance to the elderly's point of views. The use of in-depth interviews yielded social actors' meaning and interpretation of old age in their everyday experience. The findings revealed 7 important themes in relation to understanding old age; old age as a natural life cycle, old age is normal, feeling about old age, old age and physical changes, old age and religion, old age and health and old age and pondok. Finally, the interpretations of elderly residents' meaning of old age would give a clearer understanding of their needs from the local socio-cultural environment for future policy planning and implementation concerning them.
\end{abstract}

Keywords: elderly, pondok, meaning of old age, abductive research strategy, religion

\section{Introduction}

The focus of the article is to understand the concept of old age from the perspective of the elderly residents in Jeram Pondok, Kuala Selangor. At the same time, it is to explain whether pondok living arrangement is related to their understanding of the meaning of old age. Old age or ageing has been given different meanings based on different individuals or perspectives, but generally, chronological age has been applied to indicate it. Edward (1953) suggested in the earlier use of this sociological concept of old age, as it was based on functional definition was to avoid confusion. Nevertheless this use is more of a convenient indicator rather than a true expression of reality (Markides \& Mindel 1987: 12-13). Covan (2005) also used chronological age to demonstrate the difference in terms of the perception on ageing. However, in viewing old age, the elderly always compared their position to their age mates based on health. For those who were in their sixties, they were still concerned about youthful appearance, meanwhile those who were in their seventies; they began to view themselves as ageing. However, in both groups, those who had debilitating illness perceived themselves as older than their age mates who were physically healthier. The elderly who were in their eighties had accepted their old age and were at ease to discuss their physical changes. In addition, Covan (2005) also showed that religious belief had also been linked to well-being among these elderly groups. This confirmed that the chronological age alone was not an enough indicator in studying the elderly and thus other factors like health and religion could display heterogeneous perception of old age.

In the Western societies the advancement of modern medicine has given rise to the meaning of old age from the medical perspective with the deficiency model which views elderly individuals as experiencing continual deteriorating mental and physical abilities and endless diminishing personal resources and activities (Allert et al. 1994). It is a rather pessimistic view, however in reality; the elderly are varied in terms of their different abilities and have a very diverse understanding of their social reality. Therefore, being old does not necessarily mean a negative outcome since it is a part of the life cycles. In addition, Dionigi et al. (2011) studied the meanings of old age among Canadian female elderly and their levels of involvement in physical activities. They found out that inactive elderly accepted the term old age positively and saw that adaptation and levels of independence as important. The moderately active group did not view themselves as old and highly active elderly resented the term. This study shows that how an elderly person perceived old age was very much related to how active they were. However, most of the studies were carried out in the Western Christian-Judeo 
social world and much more attention needs to be paid to the elderly who reside in pondok living arrangement. Thus, the main purpose was to bring forward the meaning of old age from their own interpretation and social reality.

\section{Literature Review}

\subsection{The concept of pondok}

Pondok is an educational institution that provides religious teaching and learning with residential facilities to especially younger Muslim students from different background (Salma \& Fuziah 1998; Arena 2002; Awang 1977; Abdullah 1993). However, the physical environment, management, syllables, content and methods of instruction, target group and name, between pondoks have slight variations (Pondok Studies Development Centre 2015). More focus is given on the younger generation when studies on pondok are conducted even when the older generation start to make their presence visible (Wan Zahidi 1992; Awang 1977; Badriyah 1984; Ismail Mat \& Ismail Bakar 1993; Mohd Nasir 2008). In time,this living facility is extended later to the elderly and their being there is not pressed by educational accreditation but for religious learning opportunity and to spend their later life there. It is considered a unique living arrangement in Malaysia that caters for the elderly similar to other elderly institutions in terms of their congregated characteristic; however it is not agesegregated and has different purposes for its establishment.

Accordingly, studies on the elderly in pondok living arrangement were scarce and studies on the meaning of old age as constructed by the elderly's interpretation were even scantier. The nearest research was conducted by Haliza and Shamsuddin (2008) on positive and healthy ageing. They made a comparative study on the meaning of ageing and life satisfaction between pondok and community residents. They found out that all pondok residents accepted their old age status and thought of residing in pondok as a place to learn and practice religion. The understanding of the meaning of old age from the pondok elderly themselves would possibly identify their needs in the society and to help in formulating better policies that concern them in the future. Moreover, it could contribute to the comprehension of local theoretical conception of old age from the social actors themselves. The main objective of the article was to examine the construction of meaning of old age from the social actor's point of view, the elderly residents in Pondok Jeram. The clear understanding of the concept of old age coming from the people experiencing it could contribute in explaining the needs and requirements of this group in their everyday lives. Another objective was to explain whether being in pondok was related to the elderly residents' understanding of old age. Thus, the research question revolves around; what is the meaning of old age to the elderly in Jeram Pondok?

\section{Methodology}

\subsection{Research Strategy}

In attempting to explain the elderly's experience in the pondok and their understanding of the meaning of old age, abductive research strategy (Blaikie (2000: 114) which was rooted in interpretivism was taken up in order to shift the comprehension of individuals' experience and social reality to the scientific explanation of the social researcher. Therefore the social researcher has to enter the social world of the actors in order to comprehend the reasons and motives of their social actions and to interpret and present them based on the scientific analyses. The application of idealist ontology views social actors as those who live with shared interpretations of their behaviour within their own socio-cultural world (Blaikie (2007: 17). The elderly's meanings of old age were based on their shared interpretations of everyday lives in pondok as their social reality. Blaikie (2007: 22-23) illustrated how social constructionist epistemology could be employed.

Social constructionism explains how social actors construct their everyday reality by giving meanings to their actions, others' and their social world in the first stage. In the same manner, the social scientist constructs an understanding of the social actors' meanings and interpretations which are relevant to the study in the second stage. Therefore different socio-cultural environment would likely construct different social reality. There is also a gradual interest in the use of social constructionism in social gerontology and sociology of ageing (Bengtson et al. 2005; Alley et al. 2010). Hence, it is important for the researcher to study the elderly in their own pondok social world to understand the social meanings and interpretations of old age to them. In turn, the researcher generates the categories, concepts and themes to understand the problem. 


\subsection{Data collection}

The site of investigation was Jeram Pondok in Kuala Selangor. The pondok has been established since 2000 and as for now it has more than 100 housing units and nearly 200 elderly residents. However, since the pondok is not formally registered, many facilities are still needed to improve the lives of the elderly there. In this study, purposive sampling strategy was adopted and the criteria of the elderly chosen were those who were sixty and above, had stayed for more than a year and were willing to be included in the study. The key in using this sampling technique depends on whether sufficient data are generated to answer research questions (Mason 2002: 134). In this study the saturation point was reached after the twentieth informant was interviewed. Therefore, the use of theoretical sampling is not about the sample size but whether the information is adequate and reaches its saturation point (Corbin \& Strauss 2008: 143-146). When the elderly informants' answering pattern turned repetitive, the selection stopped. A few of the informants were interviewed more than once for clarification because of the flexibility and dynamic nature of the interviews that broadened the topic after more data were generated. At last 20 informants were selected in order to understand how they conceptualize and describe old age in relation to pondok.

The data was collected from March to April 2014 using semi-structured, in-depth interviews. Field data from observation was used as supplementary information. Each interview took around one to two hours depending on situations. All interviews were carried out in the locations that were convenient to the informants, their own housing unit except for two which were conducted at the pondok surau (place of worship smaller than a mosque). Both of these female informants were married and since the housing units were small, they were more comfortable with having the interviews in the surau.

\subsection{Data analysis}

The data collected were in a Malay language. They were audio recorded, transcribed verbatim and translated to English for coding and analyses. Thematic data analysis was carried out based on the transcribed data of the interviews. The qualitative data were analysed using computer software, Atlas.ti 7 . The focus was on searching for the relevant codes that emerged from the data and to categorise them accordingly. After the process of coding, comparing and refining, a related pattern appeared for pertinent themes to be generated.

\section{Results and Discussion}

The results from data analyses are divided into two parts: Demographic characteristics of study informants and meanings of old age.

\subsection{Demographic characteristics of study informants}

Table 1 shows the demographics of the elderly informants. There were 17 female elderly and 3 male elderly among the 20 informants. The number is not unusual because most pondoks all over Malaysia has the same sex demographics. In fact Jeram Pondok has only 12 males and more than 150 female residents. Half of the elderly were in their sixties, followed by 6 in their sixties and the least, 4 in their eighties. 15 elderly were single either through widowhood (13), divorce (1), and never married (1). All male elderly were married and only 2 female elderly were of the same status. All informants met the age criterion selection of being more than a year in pondok. To stay at least for a year is important in order to get familiar with the surroundings there. However, out of one of the elderly who had stayed more than 11 years from the beginning of the establishment of the pondok in 2000 , a male elderly was considered a rare case. He had been with the pondok for 30 years starting in his thirties as a follower to the pioneer, a revered local Muslim scholar. He started as a follower and gradually he became one of the teaching staff and an elderly resident in the pondok. 
Table 1. Demographic characteristics of study informants

\begin{tabular}{lcc}
\hline Characteristics & $N=20$ & $\%$ \\
\hline Sex & 3 & 15 \\
Male & 17 & 85 \\
Female & & \\
Age & 10 & 50 \\
$60-69$ years & 6 & 30 \\
$70-79$ years & 4 & 20 \\
80 years and above & & \\
Marital status & 1 & 5 \\
Never married & 5 & 25 \\
Married & 13 & 65 \\
Widowed & 1 & 5 \\
Divorced & & \\
Duration of stay & 6 & 30 \\
$2-4$ years & 5 & 25 \\
$5-7$ years & 6 & 30 \\
- 10 years & 3 & 15 \\
\hline and more years & & \\
\hline
\end{tabular}

\subsection{Meanings of old age}

When they were asked, what does old age mean to them?, some of them could answer straight away but some asked for clarification that made the researcher rephrased her question to how do you feel about being old or getting old? Thus, both questions comprise the meanings of old age. In addition, when these questions were asked, some of them were really surprise because they did not expect these questions. For them, it was like stating the obvious. They practically did not have a certain kind of apprehension about being old or about being in pondok. From the data analyses, the meanings of old age managed to generate 7 themes.

\subsubsection{Old age as a natural life cycle}

The questions about the meaning of or feeling about old age were something that the elderly did not ponder so much until they were asked. Many elderly informants interpreted old age as a natural life cycle. Informant 1 responded, "Old... is a life cycle that everyone experiences, to be born without knowing any natural law, educated, experience adulthood, children to old adult, really old..." For her it was a process that we had to go through. In the same manner Informant 8 explained:

We will experience old age. From young age to old age... even if do not want it we will still be old... We live the opposite is death. Everything has opposite. Healthy is the opposite of being sick. Have to accept. That is what Allah determines for us, fated, we just have to accept...

For him we were destined to have all these experiences and to start accepting their inevitability. Even difficult experiences are destined and the strong belief in religion would enable us to pass through them. In addition, Informant 9 saw old age as a natural law, "It was like that when we are old. From our late mother, grandmothers... we cannot be young forever. From being a child, we experience old age; tomorrow we will not be around... Who would replace us?" She was also indirectly implied death experience as the finality of the life cycle.

\subsubsection{Old age is normal.}

This theme is quiet similar to the first one. Being normal means that is just part of life and we have no choice but to go through it. Informant 9 said that being old is normal by implying that, "There's no need to look pretty anymore. The youth has passed." She indirectly stated the physical changes that we have to go through as a part of the normal process of old age. The same response was given by Informants 15 and 19. For both of them since it was a normal condition, there is nothing to be sad about in being old. 


\subsubsection{Feeling about old age}

When the question about feeling about old age, Informant 10 said that, "I did not feel anything..." She added that she was not angry about being old. In the same way, Informant 7 did not think much about old age and did not resent being old. For Informant 17, he felt better with old age. "I become better... felt stronger because I believe and like it here [pondok]... I did not reject or resent [old age]..." When they did not feel anything means old age has never been an issue to the elderly. However, other factors like health that could influence old age experience would have brought more attention and concern to them.

\subsubsection{Old age and physical changes}

The elderly residents realised that they were not as strong as they were before. Informant 18 mentioned that his body could not take physical work as much as he was 25 years old and he could feel the difference. Furthermore, Informant 5 stated that she was young at heart. She used to help in the pondok surau voluntarily, but lately she realised that she could not do as much work as before. Nevertheless, she was still active as one of the committee members. Informant 15, the oldest resident mentioned that she was very active with outside activities organised by the pondok. However, since she was slowly losing her strength due to old age, she restricted her movement so as not to inconvenient others when they went out. Apart from physical strength, the elderly's taste bud and sleeping pattern changed. They preferred simpler food and became a light sleeper.

\subsubsection{Old age and religion}

When talking about old age and religion, several terms were used. Informant 8 expressed that experiencing old age was about acceptance. Accepting fate and destiny as prescribed by God. His view was related to taking care of her sick wife. He accepted it as his duty and fated upon him. The same issue was raised by Informant 1, "In old age has to have preparation from Allah... Has to have acceptance, gratefulness. Have to be grateful when you live with children. Having a child, be grateful." However, Informant 13 was worried that she might not have prepared enough for the hereafter, "I am worried. We did not have enough preparation... Preparation, we do not know how much have we prepared." She was worried in spite of her involvement in various religious activities including teaching Qur'anic recitation; she was not ready for the other world. Thus, she was not concerned about being old itself, but more of whether she had sufficient time to do good deeds and fulfil religious obligations for the hereafter.

To a few elderly residents, old age is associated with death. Informant 3 talked about death in a nonchalant manner, "...for Muslims, when you are old, do not think of anything else, death... before you die you better make preparation." Getting old means thinking about death. For her, before your passing you should make preparation for the hereafter. In reality, the elderly residents were not afraid of death itself as they had accepted it as a part of the natural process. From the interviews, their responses showed that they accepted that they will die one day. However, they were more concern the manner of the death and whether they have accumulated enough good deeds for the hereafter.

\subsubsection{Old age and health}

Being healthy or able to manage oneself is one of the conditions of staying in pondok. Thus, Informant 2 viewed old age as related to her health. If she was not healthy she would not be that happy there. "I do not feel anything. I am joyful because I am healthy, because I take care of myself, If not healthy it is really not joyful... we, most importantly we take care of our health. If we are healthy we are joyful, if not healthy we would be sad always." She laughed when asked about old age because she thought that it was funny that someone wants to be young. She did not view old age as a problem. She thought of old age as a natural process that everybody experiences.

Health does not necessarily relate to old age. There were older informants who were healthier than the younger ones. For example Informant 15, who was 89 years old, just a few months ago, experienced an eyesight problem and high blood pressure. The same thing goes for Informant 16 who was 85 did not have any chronic illnesses except the natural regressive physical strength due to old age. However, she was still able to walk to the surau without a walking stick and did not wear spectacles to read. Even though all of them have a kind of illnesses, some were contracted in their younger days like diabetes, high blood pressure and cancer and some were more likely related to old age such as eyesight and hearing problems and joint pain.

Many who were considered having chronic illness, they had had it, in their younger ages, for example, Informant 3 
who had gone through several operations to treat her breast cancer and Informant 6, who had also gone through several operations to treat her cancer and amputate a few of her toes due to chronic diabetes. Anyway, as someone gets older, the probability of losing physical ability gradually is unavoidable. Correspondingly, having health problems has a compounding effect on the elderly. They were constantly worried about medical expenses and meeting medical appointments since the pondok did not offer health service facilities. In addition, to a certain extent their movement was limited but their determination to stay in pondok continued. They always prayed and wished that they did not get too sick that they had to be sent home. Then again if they were sick, they prayed that they would "go" easily and without delay so that their condition would not be a liability to their family members.

\subsubsection{Old age and pondok}

Many elderly informants viewed old age in relation to pondok. Since the admission criterion itself gave importance to someone to be of certain age, the elderly were aware of their being in pondok. Especially for Informant 3, "For me, when I see that I am old... I am already old, it is good. Living here, improve your good deeds, increase good deeds." For her it was better to make more good deeds and the best place to give this opportunity is in pondok. A number of them considered their age as a blessing because now they were being relieved from the responsibilities of earning a living and taking care of other family members. Now is the time to concentrate on what they want to do.

Exercising freedom especially in terms of how they spent their time in the pondok is considered important to elderly informants. Pondok offers a freedom to do what they want and when to do it. For example, attending congregated prayers were something that they enjoyed very much. Even though they are a part of the obligatory rituals, they preferred to perform prayers in a group. For example, Informant 1 said that it was a small investment with a bigger reward, which means congregated prayer is rewarded 27 times more than praying alone from the Islamic point of view. Besides that, attending classes in the surau is considered an opportunity to learn more about religion or to just started having the time to learn, that a number of them have missed in their younger days. Furthermore, going through their daily activities and routine depends on what and when. They are no longer forced to prepare food at certain time or clean and wash. They take their own time and they were no longer compelled to attend to others' needs.

Another practice that signifies the importance of old age is a kind of a hierarchical relationship between the old age groups in the pondok. The differences were more in terms of respect and care given rather than how much power or money that elderly individuals have. The oldest age group is more respected than the others. The age gap between someone who is in her sixties and someone in her eighties resembled a chronological age difference of a daughter and a mother or the age gap of a few years between siblings. The way they addressed each other also was reflected in terms of age. Mostly they called each other by using respectful title, for example kakak means older sister, adik means younger sister, or mak means mother. This signifies the Malay cultural aspect that emphasise social recognition of others who are older as a sense of respect.

\section{Conclusion}

Based on the intersubjective interactions between social actors, two main explanations were generated in the search for meanings on old age among the elderly in pondok. The meanings of old age are multidimensional based on the experiences of the elderly and the construction of old age is very much related to their living in pondok, their social world. They accepted the inevitability of old age as a part of a natural life cycle without resentment and sadness and pondok gave an avenue to experience a better old age social world. Hence, the conception of old age from the perspective of social actors' reality is essential to at least understand their needs in the effort of improving their lives in the society. Furthermore, more studies should be carried out in the future to discern the elderly's interpretation of old age in different socio-cultural background so as to give voice to the people who actually experience it.

\section{Acknowledgement}

The researchers would like to thank the International Islamic University of Malaysia through the provision of Academic Fellowship Scheme under Ministry of Education Malaysia which enables the study to be carried out smoothly and perfectly. 


\section{References}

Abdullah Muhammad Zin. (1993). Pengajian pondok di Kelantan: kajian kes di Pondok Pasir Tumbuh. Working paper, Kongres Pendidikan Islam Malaysia (1993), Universiti Kebangsaan Malaysia, Bangi, 9-11 December (In Malay).

Allert, G., Sponholz, G. \& Baitsch, H. (1994). Chronic disease and the meaning of old age. The Hastings Center Report 24(5): 11-13.

Alley, D. E., Putney, N. M., Rice, M. \& Bengtson, V. L. (2010). The increasing use of theory in social gerontology: 1990-2004. The Journals of Gerontology Series B: Psychological Sciences and Social Sciences 65B(5): 583-590.

Arena Che Kasim. (2002). Institusi pondok sebagai alternatif tempat tinggal bagi warga tua: satu kajian rintis di pondok Darul Hanan, Tumpat, Kelantan. Technical Report, UKM SK/17/2002 (In Malay).

Awang Had Salleh. (1977). Institusi pondok di Malaysia. In. Zainal Kling (ed.), Masyarakat Melayu antara tradisi dan perubahan, pp. 3149. Kuala Lumpur: Utusan Publications and Distributors Sdn. Bhd (In Malay).

Badriyah Haji Salleh. (1984). Kampung Haji Salleh dan Madrasah Saadiah-Salihiah 1914-1959. Kuala Lumpur: Dewan Bahasa dan Pustaka (In Malay).

Bengtson, V. L., Putney, N. M. \& Johnson, M. L. (2005). The problem of theory in gerontology today. In Johnson, M. L., Bengtson, V. L., Coleman, P. G. \& Kirkwood, T. B. L. (eds.). The Cambridge handbook of age and ageing, pp. 3-20. Cambridge: Cambridge University Press.

Blaikie, N. (2000). Designing social research: the logic of anticipation. Malden, MA: Polity Press.

Blaikie, N. (2007). Approaches to social enquiry: advancing knowledge. $2^{\text {nd }}$ ed. Cambridge, UK: Polity Press.

Corbin, J. \& Strauss, A. (2008). Basics of qualitative research: techniques and procedures for developing grounded theory. $3^{\text {rd }}$ ed. Los Angeles: Sage Publications.

Covan, E. K. (2005). Meaning of aging in women's lives. Journal of Women \& Aging 17(3): 3-22.

Dionigi, R. A., Horton, S. \& Bellamy, J. (2011). Meanings of aging among older Canadian women of varying physical activity levels. Leisure Sciences 33(5): 402-419.

Edward N. P. (1953). Toward a sociological definition of old age: A research note. American Journal of Sociology 59(1): 28-29.

Haliza Mohd Riji \& Shamsuddin Ahmad. (2008). Older persons in pondok and community: keeping positive and healthy the Kelantanese way. In Building healthy communities. Proceedings of the third international Asian health and wellbeing conference. Auckland, New Zealand. University of Auckland: 101-108.

Ismail Mat \& Ismail Bakar. (1993). Pengajian agama di institusi pondok di Malaysia. Working paper, Kongres Pendidikan Islam Malaysia (1993), Universiti Kebangsaan Malaysia, Bangi, 9-11 December (In Malay).

Markides, K. S. \& Mindel, C. H. (1987). Aging and ethnicity. Newbury Park: Sage Publications.

Mason, J. (2002). Qualitative researching. $2^{\text {nd }}$ ed. London: Sage Publications.

Mohd Nasir bin Abdul Hamid. (2008). Pondok dan madrasah perintis sistem pendidikan Islam nasional. Prosiding Seminar Antarabangsa Budaya dan Pemikiran Malaysia-Indonesis, pp. 476-484 (In Malay).

Pondok Studies Development Centre. (2015). (online). https:/lepondok.wordpress.com/ (25 March 2015).

Salma Ishak \& Fuziah Shaffie. (1998). Pondok sebagai satu pilihan tempat tinggal di kalangan orang tua. Sintok: Penerbit Universiti Utara Malaysia (In Malay).

Wan Zahidi Wan Teh. (1992). Pengemaskinian sistem pengajian pondok di Pulau Pinang. In Ismail Ab. Rahman (ed.). Pendidikan Islam Malaysia. pp. 105-118. Bangi: Penerbit Universiti Kebangsaan Malaysia (In Malay). 